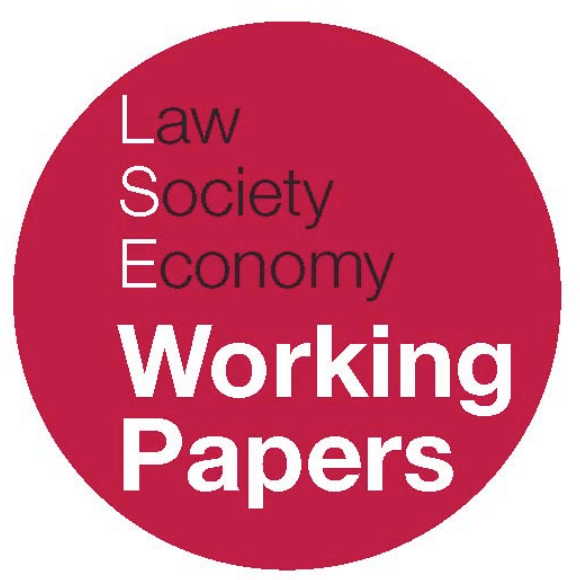

Politics, Ethics \& The Law,

Legal Practice \& Scholarship

\author{
Walter van Gerven \\ LSE Law, Society and Economy Working Papers 19/2008 \\ London School of Economics and Political Science \\ Law Department
}

This paper can be downloaded without charge from LSE Law, Society and Economy Working Papers at: www.lse.ac.uk/collections/law/wps/wps.htm and the Social Sciences Research Network electronic library at: http://ssrn.com/abstract $=1313904$.

(C) Walter van Gerven. Users may download and/or print one copy to facilitate their private study or for non-commercial research. Users may not engage in further distribution of this material or use it for any profit-making activities or any other form of commercial gain. 


\title{
Politics, Ethics \& the Law, Legal Practice \& Scholarship
}

\author{
Walter van Gerven *
}

\begin{abstract}
This paper examines legal practice, legal scholarship, ethics and politics from the viewpoint of an academic who in his lifetime has, besides having been a professor, been a vicerector, a civil servant, an advocate general and an anti-corruption officer.. As a vice-rector he acknowledged the essence of decision making: based on intuition kept in check by deliberation. As a civil servant he learned to involve considerations of general interest in the decision making process. As an advocate general he tried to combine assistance to the Court with assistance to the legal community in a multicultural and pluralist European environment. As an "anti-corruption" officer he used his judicial experience to advance reform in the EC Commission. As an academic he sought to promote the "bottom up" approach of comparative law: from judicial (and legislative) solutions to general principles which the EU member states have in common.
\end{abstract}

'Officers of Law' is not an easy subject and also a delicate one since it requires that one speak about his own personal experiences. To put these experiences in a larger context, I will start with three quotations, one anecdote and three precedents. They deal with issues recognizable to those whose life has followed a similar course. I will also try to put some order in what I say - perhaps even some general insight. The best I can hope for, though, is that these experiences may help lawyers, as they have helped me, to reflect on what we lawyers are doing when practising or studying law. The true subject of this paper is a reflection on one's own practice or, as a German jurist once put it, a 'Reflexion auf eigenes Tun'.

\footnotetext{
* Professor of Law, Katholieke Universiteit Leuven; Advocate-General of the European Court of Justice, 1988-94. This paper is the revised text of a presentation I delivered on 28 October 2008 as part of the 2008-09 'Officers of the Law' lecture series at the London School of Economics and Political Science.
} 


\section{THREE QUOTATIONS, ONE ANECDOTE AND THREE PRECEDENTS}

\section{VALUE-ORIENTED JURISPRUDENCE, 'LAST THINGS' AND ENDOGENOUS LAW}

First, three quotations which have deeply influenced me in my professional life. The first comes from two American professors at Yale University, one, Harold D. Lasswell, in political science and the other, Myres S. McDougal, in law. It is an excerpt from an article, published in the early forties, on Legal Education and Public policy. ${ }^{1}$ Lasswell and McDougal who are at the source of so-called 'valueoriented jurisprudence', write:

None who deal with law, however defined, can escape policy when policy is defined as the making of important decisions which affect the distribution of values ... We submit this basic proposition: if legal education in the contemporary world [1943] is adequately to serve the needs of a free and productive commonwealth, it must be conscious, efficient, and systematic training for policy-making... It should need no re-emphasis that $[. .$.$] democratic$ values have been on the wane in different years. The outburst of racialism in Germany is but one of several profound recessions from the ideal of deference for the dignity and worth of the individual. ... The question may be asked whether the lawyer can be held responsible in any significant degree for the plight in which we find ourselves. For a moralist, the question is whether the lawyer can be 'blamed'; for a scientist, whether he is an important causal variable; for a reformer, whether he can be acted upon to produce change. The answer to all of these questions is: most assuredly, yes.

The second quotation is older: it dates from 1869 when a small group of lawyers and philosophers (among whom was Oliver Wendell Holmes, Jr.) assembled in Cambridge, Massachusetts, to study the impact of evolutionism on the nonbiological sciences. The group wanted to shift the emphasis from 'first things, principles, categories, supposed necessities' to 'last things, fruits, consequences, facts'. ${ }^{2}$ The third quotation is an indirect one. It refers to the distinction made by F.A. Hayek ${ }^{3}$ between law seen as a body of rules of behaviour with which individuals spontaneously comply long before they are laid down in legal rules, and legislation understood as a body of rules promulgated by a number of democratically legitimated legislatures. Law in that sense is endogenous, legislation exogenous. The distinction is well known to lawyers from the common law as it coincides largely with the distinction between common law and statute law.

\footnotetext{
1 'Professional Training in the Public Interest' published in The Yale Law Journal 1942-3, 203, at 207.

2 Quoted from G. Casper, Juristische Realismus und politische Theorie im Amerikanischen Rechtsdenken (Berlin: Duncker \& Humblot, 1967); Casper has been professor of law at the University of Chicago and was later President of Stanford University.

3 In his book Law, Legislation and Liberty (London: Routledge \& Kegan Paul, 1973).
} 
These three quotations have convinced me of the necessity of value-oriented reasoning in law, of sensitivity for effects, practicality and pragmatism, and of reliance on legal reasoning that has a solid basis in societal human behavior. Recognition of values is an attitude shared by all those who, like Lasswell and McDougal, still recall World War II and the post-war reconstruction period. Sensitivity for effects and societal behaviour are, at least in my case, due to exposure to comparative law during my University studies in Leuven (1952-57) and thereafter as a teaching fellow at the University of Chicago (1959-60) where I was assistant to professor Max Rheinstein ${ }^{4}$ and his successor in 1968. Rheinstein taught American postgraduate students comparative law by asking them to find solutions for real cases drawn from different legal systems under English, French or German law. And indeed, in the words of Rudolf von Ihering (1881): '[n]obody who has had any experience as an examiner will doubt that a student is only able truly to comprehend those ideas which he can conceptualise in the concrete form of actual cases. ${ }^{5}$

\section{DECISION MAKING: INTUITION V DELIBERATION}

Now, the anecdote. It relates to my first public office (1970-76) as vice-rector for human sciences of my university, the Catholic University of Leuven (Belgium). The rector at the time was a well known virologist whilst my colleague vice-rector for natural sciences was a physics professor (both double my age). We met every week to discuss and decide university matters at the proposal of the vice-rector concerned. Most decisions were taken by consensus, sometimes we disagreed. When the rector virologist disagreed with one of his vice-rectors' proposals, he sometimes responded that it is not because a similar issue was resolved, last week, in a certain way, that the present one could not be decided differently. In other words, "precedents" did not always count for him as they always did for the physics professor. Much to my own surprise, I sometimes agreed with the rector's attitude, sometimes with that of the other vice-rector - which I then saw as a matter of choosing between two conflicting versions of justice, known in German as "Normgerechtigkeit" v "Einzelfallgerechtigkeit". The experience fascinated me so much that it brought me to write a short essay on it in Dutch under the title 'Het beleid van de rechter?, i.e., the policy of the judge, published in $1973 .{ }^{6}$

\footnotetext{
${ }^{4}$ Max Rheinstein first taught in Berlin to be later appointed, after escaping the Nazi regime, at the University of Chicago. When I was there with him also Carl Llewellyn and Soia Menchikoff had their office next to my cubicle.

${ }^{5}$ Taken from the introduction to his book Zivilrecbtsfälle obne Entscheidungen, (Jena: Fischer, 4th ed, 1881) 5. 6 W. van Gerven, Het beleid van de recbter (Antwerp: SWU \& Tjeenk Willink, 1973). The book has been rather influential for having been compulsory reading in the law curricula of some Belgian and Dutch universities. The title is interesting from a linguistic point of view because, translated in French as $\mathrm{La}$ politique du juge, it appears that in French there is no correct translation for the word "beleid", i.e., "policy". In French, the word "politics" has a double meaning: compared with English and Dutch, it means both "policy", or "beleid", and "politics", or "politiek", the latter often being used to refer to party politics. See also $n 8$ below.
} 
The main subject of the essay was to analyze the way in which judges decide a case when they must choose between different, sometimes diametrically opposed solutions which, at first sight, are based on equally valid or at least equally arguable arguments. The question then arises: is there some kind of policy argument that makes him or her choose for one or the other position? To be sure, any decision making process develops in a similar way: facts are sorted out in light of presumably relevant rules, precedents are selected which may serve as reference, interests of the parties are considered and conflicting arguments are weighed one against another. Not only legal arguments will enter into play but also meta-legal arguments (societal, economic, ethical, political) and underlying values. In the end, the outcome or solution reached will be assessed, often collegially within a court of law, to see whether it is correct and fair, adequate and equitable, and in conformity with general principles or common attitudes from which perspires a certain consensus, or at least a capability to reach one ("Kon₹̨ensfäbigkeit"). How, one may wonder, can the judge find his way through this amalgam, and how does his brain function to reach the final and hopefully most acceptable and desirable solution?

'How judges decide' is an issue which interests lawyers and psychologists immensely. Thus, for example, in a recent article published in 2007, three U.S. academics/judges examined judicial decision making on the basis of empirical research. They compared the so-called realist model [based on intuition] with the formalist model [based on deliberation]. ${ }^{7}$ They found, not unexpectedly, that neither model proves satisfactory, concluding that: '[j]udges surely rely on intuition, rendering a purely formalist model of judging clearly wrong, yet they also appear able to apply legal rules to facts, similarly disproving a purely realist model of judging'. They finally proposed 'a blend of the two which [they] called the "intuitive-override" model of judging' and described as follows:

Supported by contemporary psychological research on the human mind and by our own empirical evidence, this model posits that judges generally make intuitive decisions but sometimes override their intuition with deliberation. Less idealistic than the formalist model and less cynical than the realist model, our model is best described as "realistic formalism". The model is "realist" in the sense that it recognizes the important role of the judicial hunch and "formalist" in the sense that it recognizes the importance of deliberation in constraining the inevitable, but often undesirable, influence of intuition.

That, indeed, would seem to be the better conclusion: that "intuition" (or "judicial hunch") is kept in check and sometimes "overridden" by "deliberation" - a

${ }^{7}$ C. Guthrie, J.J. Rachlinski \& A.J. Wistrich, 'Blinking on the Bench: How Judges decide Cases' (2007) 93 Cornell Law Review 1 . The excerpts in the text are at 2 and 3 respectively. 
conclusion that is not very much different from what (many) others have concluded before. ${ }^{8}$

\section{JUDICIAL PRECEDENTS}

Finally, still by way of introduction, I will cite three precedents from the ECJ's case law. The first is the Barber judgment of 17 May 1990 where the question was whether contributions made to, and benefits payable from, redundancy payments and occupational pension schemes constitute "pay" in the sense of Article 141 EC (ex 119 EEC) ensuring equal pay for male and female workers, or rather a "social security" scheme which does not fall under that Article. 9 The second is the Parliament v Council judgment of 22 May 1990 in which the question was decided whether the European Parliament had "ius stand?" in Court to defend its legislative prerogatives against the other Community institutions notwithstanding the fact that, at the time, Parliament was not named in Article 230 EC (ex 173 EEC) among the institutions which could ask the Court to review the legality of acts adopted, to its disadvantage, by other Community institutions, in that case, the Council.10 The third precedent is the Grogan judgment of 4 October 1991 concerning the compatibility of Irish legislation prohibiting students associations to reproduce in student's agenda the list of British clinics where abortion could be legally performed. ${ }^{11} \mathrm{I}$ was Advocate General in all three cases which may enable me hereinafter to describe the impact of the Advocate General's Opinion as accurately as possible.

\section{POLITICS, ETHICS \& THE LAW}

\section{Civil SERVANTS AND JUDGES}

Judges deal with a large diversity of situations: politics and ethics are only some of them. The second of the three precedents cited above deals with politics, the third with ethics. Before discussing them briefly, I will mention another experience, not as an Attorney-General. but as a civil servant, that is, as President of the Belgian Banking Commission in the years 1982-1988, that is before becoming Advocate

\footnotetext{
${ }^{8}$ In my essay of 1973 referred to in $\mathrm{n} 6$ above, I examined judicial decision making from a viewpoint of values underlying the court's judgment; values for which it must find a foundation in so-called "topoi" (principles, rules, case law, etc.) in its legal system suggesting a common belief and somehow officially recognized consensus that is rooted in societal behavior. Even then it is for the judge, in the face of conflicting values, to make an enlightened choice, that is, knowing that there are contradicting values which have also a societal foundation, which must be balanced against one another. See at 154-158.

9 ECJ, C-262/88, Barber, judgment of 17 May 1990, [1990] ECR I-1889.

10 ECJ, C-70/88, Parliament v Council, judgment of 22 May 1990, [1990] ECR I-2041 (on the Court's jurisdiction) and of 4 October 1991 [1991] ECR I- 4529 (on the substance; n 12 below). Only the first matters here.

11 ECJ, C-159/90, Society for the Protection of Unborn Children Ireland Ltd. v Grogan, et al., [1991] ECR I- 4685.
} 
General at the ECJ. It may show the difference between decision making of judges and that of civil servants. At the time, the Banking Commission was (still is) the supervising authority of commercial banks and bank holding companies and also the supervisor of financial transactions such as take-over bids. In the latter capacity I became involved in one of the most political affairs the Commission has had to deal with: an "unfriendly" take-over-bid which the Italian business tycoon Carlos De Benedetti launched on the largest Belgian holding company, the Société Générale de Belgique (SGB), on 16 January 1988. The task of the Banking Commission was to supervise the information which bidder and target company gave to the public to allow especially small shareholders to make up their mind whether to accept the offer, or not. The affair was of huge political importance given the role which the SGB, Belgium's $\mathrm{n}^{\circ} 1$ industrial group, played in the economic and social life of the country. The situation was even more delicate because the incumbent government was a caretaking government and political negotiations to form a new government took place which, as is usual in Belgium, proved to be very complex. Surely, it is not for the government to approve the transaction but that does not prevent the matter from being extremely political because of thousands of employees and small investors were involved in the matter - on which any government would wish to be informed. For the Banking Commission and its president which were the only public authorities to be directly involved, albeit with limited competences only, the question was in how far it should take account of the "general interest", in that case, the "national" interest of the country. And indeed, the incumbent caretaker government, acting through the prime minister and the minister of finance, had mandated the Commission to follow up the situation very closely and to keep the government fully informed.

Normally, the answer to that question should be: it is not for the Banking Commission or any other public authority to involve itself in the matter, except for the limited supervisory powers the Commission has by law, which is a free market economy matter with, moreover, European cross border aspects. However, that is a largely theoretical answer in the case of a company which constitutes such an important asset for the country, specifically for investment and employment. In such a situation, it is not possible to fully ignore the national interest dimension. In that respect, a civil servant differs basically from a judge who must apply the law even tough, when there is room for interpretation, he may attribute some role to the general interest. By contrast, for a civil servant in high place the general interest is always present in the background, and may be taken into account by him as one of the interests involved, whereby it depends on the circumstances how much. He may also, I think, confer with other political and administrative authorities to find solutions which as much as possible satisfy all interests involved, public and private. This is particularly true, I think, in matters like an unfriendly takeover of a company of the size of the SGB in which the media took sometimes very partial positions, mainly in favor of the flamboyant and outspoken Mr. De Benedetti. As a result, important elements of the problem risked to remain in the dark, mainly the risk that a large holding company would 
be run as a 'one-man show' and not by a managerial team. The objective which the authorities had in mind was a more diversified management for the company with stakeholders from the North and the South of the country and of Europe. Finally the matter was not resolved as envisaged but ended with the takeover of the company by a French company (Suez) which had proclaimed itself to be "a white knight". It is clear that during the whole episode - called after the then popular T.V. feuilleton: "Dallas" but without women - the "raison d'Etat" of more than one State was at the centre of the affair. Now twenty years later and with the European Community twenty years older, things may not be that different.

\section{The European Parliament BEFore The COURT: ARguments MATTER}

I now turn to the precedent mentioned in the preceding section that relates to politics : the ECJ's judgment in Parliament v Council.12 In that judgment, known as the "Chernobyl" judgment, the question arose whether the European Parliament had "ius stand" before the ECJ to defend its legislative prerogatives against other institutions by asking the Court to review the legality of acts adopted by these other institutions, in that case the Council, in violation of Parliament's legislative rights. At that time, Parliament was not given such competence in Article 173 EEC (the Article was later amended by the Treaty of Maastricht and again, now Article 230, broadening its scope even further by the Treaty of Nice). In the "Chernobyl" judgment, the Court answered the question in the affirmative. However, in an earlier judgment of 27 September 1988, known as the "Comitology" judgment, ${ }^{13}$ the Court had denied Parliament this right arguing that a positive answer would have been contrary to the institutional balance - as (then) laid down in the Treaties.

Between "Comitology" and the "Chernobyl" there was however an important factual difference: in "Comitology", the Commission had defended the same position as Parliament in favor of the latter's legislative prerogative (and could therefore, the Court found, defend Parliament's legal position without ambiguity) whilst in "Chernobyl", the Commission took in that specific matter the same position - unfavorable for Parliament - as the Council. To convince the Court to overrule it's earlier judgment, the A.G. (as I then was) used another line of reasoning, namely that the distribution of competences between the institutions is not only a matter of institutional balance but that it has also a protection of legal rights dimension - meaning in the case before the Court that Parliament should itself be allowed to have access to court in order to defend its own legislative prerogatives instead of to have to rely therefore on the Commission. The Court followed that reasoning. The distinction may seem to be a thin distinction but it is not: one's right to have access to court to defend its right is a fundamental right

\footnotetext{
12 ECJ, C-70/88, Parliament v Council, n 10 above (on the Court's jurisdiction which it affirmed). In a later judgment, [1991] ECR I- 4529, the Court decided on the substance as to whether Parliament's legislative prerogatives had been breached, answering the question in the affirmative.

13 C 302/87, Parliament v Council, [1988] ECR 5615.
} 
which, in a rule of law context, must be ensured by the courts on their own initiative; by contrast, in a context of institutional balance, the distribution of competences is a matter for the constitutional legislature to be decided. ${ }^{14}$ In other words, the former is purely legal matter which is for the courts to decide, even although it has political consequences; the latter is a political matter and is for the constitutional legislature to decide.

\section{HUMAN RIGHTS V ECONOMIC FREEDOMS}

The other precedent, the third mentioned before: the ECJ's judgment in Grogan, relates to ethics. It concerns the compatibility with Community law, more specifically with Article 59 EEC (now 49 EC), of Irish legislation prohibiting students associations to reproduce in students' diaries the list of British clinics where abortion can legally be performed. ${ }^{15}$ The question was whether the Irish High Court was obliged to set aside an interpretation of Irish law - based on a recently by referendum approved constitutional provision - prohibiting assistance, i.e. information, given to pregnant women for being incompatible with a fundamental economic freedom expressly recognized by the EC Treaty. The Court decided that, in the absence of any payment or remuneration being received by the student organizations, distributors of information, from the providers of the actual medical service, the connection between the information ban and the freedom of services was "too tenuous" to attract the application of Article 49 EC. The question remains however whether the regulating State (Ireland) may restrict the access of its citizens to services in another State where the services are legal (the UK), for instance by prohibiting traveling assistance to the UK. In my Opinion I thought that a prohibition for pregnant women to travel abroad in such circumstances, or a rule that upon returning to their country of origin, they would be subjected to undesired examinations, would be a disproportionate limitation of the freedom of services that cannot be justified by an imperative requirement. ${ }^{16}$

An important underlying issue concerns the relationship between basic human rights, as laid down in the ECHR, and fundamental economic freedoms, as expressed in the EC Treaty (in Grogan between the right to life as interpreted in the Irish Constitution and the freedom of receiving a medical service abroad). More specifically, is there some hierarchy between both categories, i.e., between basic rights embodied in international or constitutional provisions, and fundamental freedoms explicitly recognized by the Community Treaty? In my view there is

${ }^{14}$ See paras 6 and 7 of my Opinion in C-70/88 decided by judgment of 22 May 1990, n 10 above.

15 ECJ, judgment of 4 October 1991, C-159/90, Society for the Protection of Unborn Children Ireland Ltd. v Grogan, et al., [1991] ECR I- 4685.

16 Para 29 of the Opinion in Case C-159/90, n 11 above. In Open Door Counselling and Dublin Well Women v Ireland, concerning the same legislation and the same facts, the ECtHR (judgment of 29 October 1992, Series A, $n^{\circ} 246$; (1993) EHRR 244) came to the conclusion that the absolute and perpetual nature of the Irish injunctions against the organizations offering advice was, of itself, disproportionate. In other words even the ban on information given by students was disproportionate according to the Human Rights Court. 
none, but the importance of each category and the degree of protection of each, will have to be weighed in each concrete situation by the judge. An illustration is the ECJ's judgment in Schmidberger ${ }^{17}$ where, in the terms of the Court, there was a

need to reconcile the requirements of the protection of fundamental rights in the Community with those rising from a fundamental freedom enshrined in the Treaty and, more particularly, the question of the respective scope of freedom of expression and freedom of assembly, guaranteed by Articles 10 and 11 of the ECHR, and of the free movement of goods, where the former are relied upon as justification for a restriction of the latter.

As could be expected, the Court resolved the question by means of the proportionality principle under which it is for the court applying the ECHR to balance objectives of general interest against the principle of freedom of expression. In the specific case the Court found that the Austrian authorities had not breached Community law in giving precedence to the demonstrators' freedom of expression and of assembly over the transporter's right to free movement of goods. An important element in the evaluation was that the Austrian authorities, by allowing a thirty-hour demonstration by an environmental association on the Brenner motorway pass with the result that heavy goods traffic between Germany and Italy was interrupted for four consecutive days, had cooperated with the organizers of the demonstration to ensure that the demonstration went off smoothly. The same proportionality principle made me say in my Opinion in Grogan (see above) that a prohibition for pregnant women to travel to the UK, or of assisting them by making their travel arrangements, to have there a legal abortion - instead of, as was the case, only banning the mentioning of UK clinics where abortion could be performed in students' diaries - would have been a disproportionate restriction of the women's right of free movement.

\section{THE SANTER COMMISSION'S RESIGNATION IN 1999}

\section{EXTRA-JUDICIAL ADVICE IN POLITICAL MATTERS}

Scandals involving politicians are often the occasion for enhancing the accountability of office holders, ministers in the first place. ${ }^{18}$ That is also the case for the EU where the President and Members of the Commission are in a similar position as the Prime Minister or Chancellor and his/her cabinet ministers in Member States with a parliamentary system. Typical for a parliamentary system is

\footnotetext{
${ }_{17}$ Case C-112/00, Schmidberger v Austia, [2003] ECR I-5659, at [77].

${ }^{18}$ For a description of a few recent scandals in some of the Member States and the way in which they are handled in that State's political system, see W. van Gerven, The European Union. A Polity of States and Peoples (Oxford: Hart Publishing, 2005) 69-80.
} 
that the executive government is accountable to the majority of an elected parliament which can force the government as a whole, or ministers individually, to resign if that majority withdraws its confidence in it, him or her. Although the Commission is not a government and its president and members are not a prime minister and ministers respectively in the full sense of the word, they can nevertheless be made to resign 'as a body' by a 'motion of censure ... carried by a two-thirds majority of the votes cast, representing a majority of the Members of the European Parliament' (Article 201 EC).

In the EC/EU's fifty years of existence, the procedure has never been applied in full but it came very close to completion in 1999 when allegations of mismanagement and nepotism were raised in the European Parliament against some Members of the Commission (then under the presidency of Mr. Santer), mainly against Mrs. Cresson, a former French socialist prime minister. Probably, a motion of censure would have been voted if the two major political parties had not disagreed on whether the whole Commission should be made to resign, as Article 201 EC provides, or only Mrs. Cresson. In the absence of a qualified majority for the first alternative, or pressure to make Mrs. Cresson to go away, the European Parliament decided to install a committee of five, so called independent experts, three in auditing and two in law (of which I was one). The committee examined the allegations and interviewed several of the Commissioners, mainly those who had come under attack, but also some, amongst whom the President, who could provide the committee with useful information. When the report was submitted to the Parliament in the afternoon of 15 March 1999, the Commission decided, that same night and of its own initiative, to resign as a body - but stayed on as a caretaker Commission until the appointment of the new Commission led by Mr. Prodi. ${ }^{19}$ In itself, the Commission's decision to resign as a whole appear to be rather harsh given the fact that the committee had not found fraud or corruption in the members of the Commission, but had found evidence of only one case of nepotism at the charge of Mrs. Cresson - who, later on, was also found guilty by the ECJ. ${ }^{20}$ If the Commission, nevertheless, took the decision to resign collectively, that was because the committee had held the whole Commission responsible for the malfunctioning of a program for which the same Mrs. Cresson was held responsible. The committee was of the opinion that:

\footnotetext{
19 For a full account, see W. van Gerven, 'Managing the European Union: For better or for worse?' in B.S. Markesinis (ed), The Clifford Chance Millenium Lectures. The coming together of the common law and the civil law, (Oxford: Hart Publishing, 2000) 91-104.

20 ECJ judgment of 11 July 2006, Case C-432/04, Commission v Cresson [2006] ECR I-6387. The Court opined that Ms. Cresson had given precedence to her personal interests by being personally involved in the appointment of a close friend as a personal adviser in her cabinet, in circumvention of standing rules, which the Court regarded as a breach of a certain degree of gravity of the obligations arising from her office as Commissioner. However, the Court considered this finding, of itself, as an appropriate penalty without there being a need, as asked by the Commission, to be deprived of her right to a pension (paras 150-1). But see the Opinion of A.G. Geelhoed who had proposed to deprive the former Commissioner of her pension right up to 50\%: see paras 124-126 at [2006] ECR I- 6424.
} 
the allegations raised $\ldots$ at an early stage of operation, and even before ..., were so serious and illustrative of a dysfunctional organizational climate and structure that they should have been seen by those who were in charge. They are the demonstration of the weaknesses of the information channels and control mechanisms within the Commission, up to the highest level. ${ }^{21}$

After the Commission's resignation the same committee was asked to analyze in a second report the Commission's 'current practice and proposals for tackling mismanagement, irregularities and fraud.' That report was submitted to the European Parliament on 10 September 1999. It contained 286 pages with more than 90 recommendations. ${ }^{22}$ Chapter 7 dealt with the subject of integrity, responsibility and accountability in European political and administrative life.

\section{The Member States’ Legal heritage as A MODEL}

Needless to say that, in its two reports, the committee drew to a large extent on the legal (and auditing) heritage of the Member States. That was particularly true for the introduction of the first report for which the committee members had to rely on their own knowledge to describe and analyze the status and independence of the committee, the scope of its inquiries, the nature of reprehensible acts to be examined, the standards of proper behavior to be applied, and the kind of responsibility to be used as a benchmark. Particularly the nature of reprehensible acts - described in the Parliament's mandate to the committee as 'fraud, mismanagement and nepotism' - was a difficult issue for the committee: did this terminology only refer to administrative irregularities ("irrégularités administratives"), or did it also encompass ethically reprehensible behavior and infringements of principles of sound administration? After some discussion the committee chose for the broader view. ${ }^{23}$ In preparing its second report ${ }^{24}$ the committee of independent experts was bound to draw even more inspiration from the Member States' constitutional laws and traditions. That was particularly true for chapter 7 where important issues of a constitutional nature had to be considered, such as laying down codes of conduct for Members of the Commission, their cabinets and

21 Point 1.6.1. of the Committee's first report quoted in the article, n 19 above, at 97. The full title of the report is First report on Allegations regarding Fraud, Mismanagement and Nepotism in the European Commission (15 March 1999).

${ }^{22}$ For a discussion of the role of the committee and an important part of its recommendations, see P. Craig, EU Administrative Law (Oxford: Oxford University Press, 2006) 1-30.

23 At 1.4 .5 of the first Report. For this and other points, and in the absence of written rules, the committee drew inspiration from the 'Seven principles of public life' as set out in the first report on Standards in Public life of the UK (then Nolan) Committee. Actually, the committee itself, as set up by the European Parliament, may have been modelled after the British "ad hoc" tribunals of inquiry: strangely enough, because for the creation of the committee, the European Parliament might have found a solid legal basis in Article 193 EC Treaty which allows the European Parliament, 'at the request of a quarter of its Members, to set up a temporary Committee of Inquiry to investigate ... alleged contraventions or maladministration in the implementation of Community law ...'. It is unclear why that provision has not been used.

24 Second Report on Reform of the Commission. Analysis of current practice and proposals for tackling mismanagement. 
administration, describing the political - individual and collective - responsibility of Commissioners for own conduct and for that of 'their' civil servants, and addressing other delicate issues such as the Commission's attitude vis-à-vis whistle-blowing, civil disobedience and, particularly, procurement contracts for outsourcing of services and projects. Especially the last topic was at the centre of the allegations which the European Parliament had asked the committee to investigate. The major difficulties that had arisen were:

the blurring of the line between policy formation and policy implementation; the difficulty of ensuring proper financial accounting in relation to the activities undertaken by the private contractor; the importance of a proper line of management within the public body; and the fact that the private contractor will normally not be imbued with a public ethos in it decisionmaking. ${ }^{25}$

Paul Craig assessed the committee's presentation of this important issue, and its limits and merits, as follows:

[The] report performed a valuable function in bringing together data on the problems encountered in the running of a number of important Community policies. It is moreover no bad thing in the long term for the Commission to have been publicly criticised in this manner, since there were doubtless those in the Commission who were arrogant, personally and 'institutionally', to others in the Community... These lessons must not be forgotten. It should nonetheless be acknowledged that there will often be no viable alternative to contracting out for the effective discharge of many Community policies (...) The objective must be to develop techniques to ensure that contracting out functions as an effective and efficient mechanism for provision of Community public services. ${ }^{26}$

\section{JUDICIAL PRACTICE, LEGAL SCHOLARSHIP AND JUDICIAL POLICY}

\section{JUDGE AND JUDICIAL PRACTICE, THE DOMINANT MODELS IN SCHOLARSHIP}

There is a close relationship between judicial practice and legal scholarship. Legal scholarship focuses primarily on judicial practice. ${ }^{27}$ The most evident illustration of the intertwinement between scholarship and judicial practice is the form of legal literature known as "annotation". It originated in France when, with the codification

25 n 22 above, 5.

26 ibid, 5-6.

27 On this, see J.B.M. Vranken, Exploring the jurist's frame of mind (Deventer: Kluwer, 2006) $115 \mathrm{ff}$. 
movement in the beginning of the $19^{\text {th }}$ century, primacy in legislation shifted to the legislative branch and the academia and the judiciary had to look for new roles. ${ }^{28}$ The aim of annotators, "les arrêtistes", mainly distinguished professors, was not only to analyze and explain the annotated decision, to uncover its background and to link it to earlier decisions or other areas of the law, but also to suggest alternative solutions, and try to foresee and help shape future developments. Their task was all the more considerable in France because of the apodictic style of decisions of the Cour de cassation, annotators often having to guess the reasons and arguments behind them. ${ }^{29}$ However, not only annotations focus on judicial practice; the judge is also - and not only in France - the dominant model in scholarship. That implies that 'in scholarship, as in practice, the focus is on cases, and the methods are aimed at resolving disputes in the same way as in adjudication. 30 It also means that 'where legal education is strongly oriented to case law it mainly presents law as a product of dispute and disorder. ${ }^{31}$ Most scholarship is not only focused on judicial, therefore litigation-oriented practice, 'the predominant approach to law is' moreover 'still legal-dogmatic: deriving its arguments from the interpretation of rules, principles, precedents and doctrines, which are assumed to form a coherent whole.' If legal-political choices are present, they 'are disguised as interpretations, and the factual basis of many arguments is intuitive rather than empirical.' 32

However that may be, as Dutch scholar Jan Vranken points out, this does not preclude the possibility of another type of legal scholarship, one "[that] should divorce itself from current law and the judge as a model, but develops its own agenda and develops its own method. ${ }^{33}$ Thereby, scholarship is meant which is carried out not only by scholars who are free and independent in forming and pronouncing their opinions but who are also free from solving concrete practical problems. This other more theoretical and less doctrinal form of scholarship is most visible in the United States where, at the end of the nineties, there has been an apparent shift to theoretical scholarship for which interdisciplinarity is often cited as a major cause. Vranken again: '[i]nstead of a perspective that is internal to law, an approach that uses instruments and insights from other disciplines such as economics, cognitive psychology, anthropology and sociology is becoming increasingly prevalent. ${ }^{34}$ To the extent even that some express their disappointment 'not to find more in the law reviews that is of value and pertinence to our cases. ... The concern that academics are writing for each other is indeed

\footnotetext{
28 ibid, 117.

29 ibid.

30 ibid, 120.

31 ibid, referring to R. Cotterrell, 'Subverting Orthodoxy, Making Law central: a View of sociological studies' (2002) 29 Journal of Law and Society 632, 639. 'Dispute and disorder' as opposed to 'encouraging trust and agreed on solutions'.

$32 \mathrm{n} 27$ above, 122. An example thereof is European integration that is clearly a political objective but is often disguised as a legal principle.

33 ibid, 125 .

34 ibid, 97.
} 
well founded.' 35 This shift from practical and doctrinal to theoretical and interdisciplinary scholarship is also visible in Europe, for instance regarding European law, where 'the dismissive attitude of American theoretical scholars towards doctrinal analysis has sometimes infected EU law scholarship', 36 although not to the same extent, it would seem, as in the U.S. That may be because in Europe the 'multiple legal autonomies represented in the EU are perhaps one of the features that make its law such a rich subject for doctrinal study. ${ }^{37}$ Even a legal pioneer like economic analyst of law, Richard Posner, maintains that '[d]isinterested legal-doctrinal analysis of the traditional kind remains the indispensable core of legal thought.'38

\section{THE POLICY OF THE JUDGE}

In general, 'policy' refers to a course of action adopted or proposed by an organization or person, more specifically an action which implies a choice of one action among several. Choices need to be made because of the multiplicity of objectives, or plurality of values, and the scarcity of means or resources. In that broad sense also judges make choices when alternative solutions are submitted to their judgment which they can alternatively adopt depending on the room for interpretation inherent in the legal system. In making these choices they are guided by underlying values laid down in written or unwritten rules, or principles, of a procedural or a substantive nature. An example of the former is the need to pursue legal certainty through consistency of terminology and coherence of the legal system as a whole. An example of the latter is the need to provide equal protection in law and pursue justice. Obviously, such multiplicity of objectives and plurality of values allow judges to make choices, to prefer distributive above corrective justice for example. ${ }^{39}$ Obviously, in making such choices judges should not follow their subjective preferences but follow preferences presumably based on some societal consensus or capability to reach one. In a democracy, policymaking goes hand in hand with transparency: that includes judges which must reveal, if not to the public at large, then at least to the parties directly involved or

\footnotetext{
35 J.S. Kaye, 'One Judge's View of Academic Law Review Writing' (1989) 39 Jnl. Leg. Educ. 313, 319-20.

36 A. Arnull, 'The Americanization of EU Law Scholarship' in A. Arnull, P. Eeckhout \& T. Tridimas (eds) Continuity and Change in EU Law. Essays in honour of Sir Francis Jacobs (Oxford: Oxford University Press, 2008) 414-431, at 424 .

37 ibid, 430.

38 Quoted by Arnull in ibid, 431 where, at 430-431, also other similar opinions are recorded. See also J. Vranken, n 27 above who at 122, writes: 'The legal-dogmatic approach seems to have a strong foundation.... Dogmatism is an essential source of knowledge in achieving the core principles of law: universality, repeatability, transparency and criticism.' He would 'advocate a division of 75 percent dogmatism as described above, and 25 percent free thought' (ibid, 124).

39 See Lord Steyn's speech in Macfarlane v Tayside Health Board concerning a damages claim for a healthy child born as a result of an unsuccessful vasectomy. From a perspective of corrective justice, Lord Steyn observed, somebody who has harmed another without justification must indemnify the other. But from the vantage point of distributive justice, the focus is on the just distribution of burdens and losses among members of a society. If approached in this way, an overwhelming number of ordinary men and women may be of the opinion that the compensation of harm consisting in the birth of a healthy child is not a priority. See also the reference to Lord Steyn's speech in the text accompanying $n 76$ below.
} 
to the legal or other community directly concerned, the reasons, arguments and ways of reasoning adopted to make up their mind and come to conclusions. In this context, motivation of judicial decisions is an essential requirement which should not be limited to strictly legal reasoning but should also relate as much, perhaps even more, to the (underlying or concomitant) meta-legal reasoning ("Vorentscheidung" in Esser's terminology). In this respect there are large differences between legal families, ${ }^{40}$ although one should not jump too soon to conclusions because of the existence, as is the case of the French Cour de cassation, of a double discourse of argumentation, one cryptic published and open to the public, and another argumentative but hidden and only open to the magistrates. ${ }^{41}$ In such a case the gap between the two discourses will often be filled in Opinions or reports of Procurators General, Advocates General, or Commissaires du gouvernement. In fact those opinions and reports play often the same role as annotations, but in a more authoritative way, or of concurring or dissenting opinions.

\section{GENERAL PRINCIPLES, JUDICIAL ACTIVISM AND SUBSTANTIVE EQUALITY}

\section{THE BARBER ISSUE AND THE PRINCIPLE OF EQUALITY}

I now turn to the first of the three precedents mentioned at the outset of my presentation: the ECJ's judgment in Barber (followed by a host of judgments in post-Barber cases). As already mentioned, the policy aspect of legal (particularly judicial) decision making is most apparent when the judge is confronted with, and must choose between, two impeccable forms of legal reasoning which lead to opposite results. Choices have then to be made between underlying values, involved interests and equitable solutions. And, indeed, choices had to be made in the Barber case (in which I was involved as Advocate General). The major issue was whether contributions made to, and benefits payable from, redundancy payments and occupational pension schemes (only the latter are discussed herein) constituted "pay". The point was decided by judgment of 17 May 1990.42 Obviously, on the specific question the Court could go two ways: either decide that an occupational (contracted-out) pension scheme constituted pay and fell under the gender-equality principle of Article 119 (now 141) - which requires 'each Member State [to] ensure that the principle of equal pay for male and female

\footnotetext{
${ }^{40}$ See W. van Gerven, 'Bringing (Private) Laws Closer to each other at the European Level' in Fabrizio Cafaggi (ed), The Institutional Framework of European Private Law (Oxford: Oxford University Press, 2006) 37-77, at 40-43.

41 See M. Adams and F. Tanghe, 'Legitimacy and democracy through adjudication. Comparative reflections on the argumentative practice of the French and Belgian Cour de cassation' in N. Huls, M. Adamns and J. Bomhoff (eds), The Legitimacy of Highest Courts' Rulings. 'Judicial Deliberations' and beyond (The Hague: TMC Asser Press, 2008).

42 n 9 above; Opinion Adv. Gen. van Gerven, at I-1912-1943.
} 
workers for equal work or work of equal value is applied' - or decide that, because the scheme was a substitute of a social security scheme, it did as such fall outside the scope of Article 119 EC. 43

Both answers could be argued in light of earlier case law. However, the first interpretation was supported by the principle of equality of which the Court has consistently said, before and after Barber, that it is a fundamental principle of the Community legal order. And, indeed, in the Advocate General's Opinion the principle of equality figured as a key argument albeit, as the A.G. did not neglect to point out, that this broad interpretation of Article 119 (now 141), certainly in its initial version (n 43 above), might encroach upon the Member States' competences in matters of social policy as laid out in Articles 117 and 118 (now 136 and 137 EC). ${ }^{44}$ By and large, the Court came to the same conclusion as its A.G., holding that a contracted-out scheme 'constitutes consideration paid by the employer to the worker in respect of his employment and consequently falls within the scope of Article 119 of the Treaty. ${ }^{35}$ In terms of the aforementioned article of Chris Guthrie et al. (n 7 above), one might say that the "intuitive" ('first hunch') approach - pension constitutes postponed salary - was, according to the A.G. and the Court, not overridden by the "deliberative" ('after reflection') approach - according to which the contracted out scheme was a substitute of a social security scheme and should therefore also be assimilated to it legally.

\section{GENERAL PRINCIPLES: JUDICIAL ACTIVISM V AN ONGOING PROCESS OF LAWMAKING}

In the Barber case an important role was played by the general principle of equality. It was especially relied on in the A.G.'s Opinion where it was presented as part of an extensive discussion of arguments and counter-arguments examining the positions advanced by the parties -and thus as part of strict legal reasoning. ${ }^{46}$ That is not always the case: often principles are used to permit judges a flexibility which may show a court's inclination to policy-mindedness and activism - for what the ECJ has

\footnotetext{
${ }^{43}$ In which case it could still fall within the scope of existing gender equality directives which, however contrary to Article 119 (now 141) EC - do have no horizontal effect under the Court's case law. In its initial version Article 119 had only two paragraphs, using almost the same wording as the first two paragraphs of the present Article 141 EC.

${ }^{44}$ Para 30-31 of the Opinion. See for a comment N. Burrows and R. Greaves, "Walter van Gerven and the principle of equal treatment of men and women' in The Advocate General and EC law (Oxford: Oxford University Press, 2007) 89-125, at 106 where the authors say that the A.G. 'teased out for the Court the way in which the principle of equality could inform its decision and allow the Court to interpret Article 141 in a way that did no violence to the text of the Treaty.'

${ }^{45}$ Para 28 of the Barber judgment, $\mathrm{n} 9$ above.

$46 \mathrm{It}$ is exceptional for a court, at least on the continent, to admit explicitly that it makes policy decisions, as for example Lord Denning did in Spartan Steel \& Alloys Ltd v Martin \& Co Ltd [1973] QB 27, [1972] 3 All ER 557. He bluntly said: 'At bottom I think the question of recovering economic loss is one of policy. Whenever the courts draw a line to mark out the bounds of duty, they do it as matter of policy so as to limit the responsibility of the defendant. Whenever the courts set bounds to the damages recoverable saying that they are or are not, too remote - they do it as matter of policy so as to limit the liability of the defendant.'
} 
sometimes been strongly criticized. ${ }^{47}$ Thus, and not entirely without reason, in a study published in August 1995 by Sir Patrick Neill QC, in which the author examined various leading ECJ judgments, 48 to conclude that '[T]he cases ... provide many examples of judicial activism. The methods of interpretation adopted by the ECJ appear to have liberated the Court from the customarily accepted discipline of endeavoring by textual analysis to ascertain the meaning of the language of the relevant provision.... ${ }^{49}$ To put this conclusion in its proper context, one must realize though that most of the judgments examined by Sir Patrick refer to the issue of legal protection of rights which individuals, or institutions, derive from Community law, and to the remedies which Community law and domestic laws should, according to the ECJ, make available for such individuals or institutions..$^{50}$ In other words, all or most of them judgments in matters which belong to the hard core of judicial activity: protecting rights of individuals, and granting legal remedies therefore.

In Community law, the principle of equality has known an interesting development: it has been the object of an ongoing process of law making in which Court and legislature (of primary and secondary law) have constantly interacted with one another. Starting as a prohibition of discrimination on the basis of nationality, and of gender (but only in a limited way, and partly for economic reasons: see Article 119 , now $141 \mathrm{EC}$, in its initial version), it developed into a general constitutional right to equal treatment unconnected with nationality or gender ${ }^{51}$, to be finally incorporated, by the Nice Treaty, as a general probibition of discrimination in Article 13 of the EC Treaty. ${ }^{2}$ In light of this long partly judicial, partly legislative evolution, the invocation of the principle of equality can hardly be seen as a sign of judicial activism. However, the recent judgment of the Court in Mangold ${ }^{3} 3$ may have shown that the principle can nevertheless be overstretched. The judgment concerned alleged discrimination on the basis of age under a German law that allowed the conclusion of employment contracts for a definite period of time for persons older

\footnotetext{
47 See particularly H. Rasmussen, European Court of Justice (Copenhagen: GadJura Thomson, 1998). For a follow up, in light of the Court's expansion with an increasing number of Member States, see id, 'Present and Future European Judicial Problems after Enlargement and the post-2005 Ideology Revolt' (2007) 44 Common Market L. Rev. 1661.

48 Amongst which Van Gend \& Loos, Costa v ENEL, Francovich, 'Les Verts', Foto-Forst and Marleasing. See 'The European Court of Justice. A case study in Judicial Activism' in House of Lords Select Committee on the European Communities, 1996 Intergovernmental Conference, Minutes of Evidence, House of Lords session 1994-1995, 18 th report, 1995.

${ }^{49}$ House of Lords Select Committee on the European Communities, ibid, at 47.

50 See further W. van Gerven, 'Community and national legislators, regulators, academics and practitioners: living together apart?' in B.S. Markesinis (ed), Law Making, Law Finding, and Law Shaping. The diverse influences (Oxford: Oxford University Press, 1997) 13-35, at 29-30. By contrast, when the ECJ interprets 'ordinary' cases, such as interpreting regulations or directives - with the exception of directive provisions which are the prolongation of basic Treaty provisions - the Court would seem to apply very orthodox interpretation methods. See e.g. ECJ, Case C-441/93, Pafitis et al., [1996] ECR I- 1347, ibid, at $13-21$.

51 On this evolution, see G. More, 'The Principle of Equal Treatment: from Market Unifier to Fundamental right?' in P. Craig and G. de Burca (eds.), The Evolution of EU Law (Oxford: Oxford University Press, 1999) 517-53. For the initial version of Article 119 see n 43 above.

52 See W. van Gerven, $n 18$ above, 171-182, comparing with the situation in the United States.

53 Judgment of 22 November 2005 in C-144/04, [2005] ECR I-9981.
} 
than 52 years, but not, or to a lesser extent, for those younger than 52 years - the general rule being that, in order to avoid abusive dismissals, employment contracts must be concluded for an indefinite period of time. The ECJ stated:

Directive 2000/78 does not itself lay down the principle of equal treatment in the field of employment and occupation. ... [T] he sole purpose of the directive is 'to lay down a general framework for combating discrimination on the grounds of religion or belief, disability, age or sexual orientation', the source of the actual principle underlying the prohibition of those forms of discrimination being found, as is clear from the third and fourth recitals in the preamble to the directive, in various international instruments and in the constitutional traditions common to the Member States. - The principle of non-discrimination on grounds of age must thus be regarded as a general principle of Community law (italics added). (rec. 74-75).

Upon which the Court concluded in the judgment's dictum:

Having regard to ... the foregoing, the reply ... must be that Community law and, more particularly, Article 6(1) of Directive 2000/78 must be interpreted as precluding a provision of domestic law such as that at issue in the main proceedings which authorizes, without restriction, ... the conclusion of fixedterm contracts of employment once the worker has reached the age of $52.5^{54}$

The Mangold judgment has been severely criticized by the late A.G. Geelhoed in his Opinion of 16 March 2006 in Chacon Navas, 55 and by A.G. Sharpston in her Opinion of 30 November 2006 in Lindorfer/Council.56 In Palacios de la Villa, ${ }^{57}$ the Court's solution in Mangold is strongly rejected by A.G. Mazák in his Opinion of 15 February 2007 who writes:

The approach adopted by the Court in Mangold received serious criticism from academia, the media and also from most of the parties to the present proceedings and certainly merits further comment (par. 83). - First of all, it should be emphasized that the concept of general principles of law has been

\footnotetext{
${ }^{54}$ One may think that the imperfection of this judgment - which, as mentioned later in the text, has been strongly criticized - was due to the novelty of the composition of the Grand Chamber, set up by the Nice Treaty, by which the judgment was rendered. On this issue, see Rasmussen, n 47 above, at $1668 \mathrm{ff}$ of his article in CMLRev. If that is so, the task of Advocate Generals to keep the record straight may have become even more important with the latest enlargements of the ECJ which now counts (the excessive number of) 27 judges.

55 Judgment of 11 July 2006, case C-13/05, [2006] ECR I- 6467; Opinion at I-6471, par. 38-56 (where Mangold is named).

56 Case C-227/04P, Lindorfer v Council, judgment of 11 November 2007, [2007] Staff case.

57 Case C-411/05, judgment of 16 October 2007, [2007] ECR I- 8566. In his Opinion the A.G. also criticizes - rightly, I think - the position of the Court in Mangold in so far as it ascribes horizontal direct effect to the general principle of equality: paras. 132-137. See also P. Craig \& G. De Búrca, EU Law (Oxford: Oxford University Press, 4th ed, 2008) 412.
} 
central to the development of the Community legal order ... (par. 84).- It is nevertheless possible to reflect on the soundness and conclusiveness of the reasons on which the Court based its findings in Mangold concerning the existence of a general principle of non-discrimination on grounds of age ... (par. 87). - It is therefore correct to state, as the Court did with regard to prohibitions of discrimination on specific grounds, that specific prohibitions constitute particular expressions of the general principle of equality which forms part of the foundations of the Community. However, to infer - as the Court did in Mangold - from the general principle of equality, the existence of a probibition of discrimination on a specific ground is quite different and far from compelling. (par. 94; italics added).

That would seem to be the right conclusion.

\section{FORMAL V SUBSTANTIVE EQUALITY, AND POSITIVE DISCRIMINATION}

In their comment on Barber, N. Burrows and R. Greaves point out that the A.G.'s understanding of the principle of equality in his (my) Opinion in Barber 'was limited to one of seeing equality in formal rather than substantive terms... [That remark] was in reference to the fact that, having achieved equality, the position of women was seriously disadvantaged and men's position was not improved. 58 They state that the A.G.'s understanding of the principle was in contrast with a substantive view of equality, as adopted for example by the UK Minister Barbara Castle, 'who introduced a different pensionable age for men and women as a compensatory device designed to recognize the double burden of work taken on by women who had family or other caring responsibilities. ${ }^{59}$ The point raises the issue of 'affirmative' or 'positive' action which, in the EU, was made possible by the addition by the Treaty of Amsterdam (1997) in Article 141 (ex 119; n 43 above) EC of a new paragraph (4) according to which:

With a view to ensuring full equality in practice between men and women in working life, the principle of equal treatment shall not prevent any Member State from maintaining or adopting measures providing for specific advantages in order to make it easier for the underrepresented sex to pursue a vocational advantages or to prevent or compensate for disadvantages in professional careers. ${ }^{60}$

Also before the Treaty of Amsterdam, Article 2 (4) of Council Directive 76/207 of 9 February 9, 1976, permitted measures of positive action as regards access to employment, vocational training and promotion, and working conditions on the

\footnotetext{
$58 \mathrm{n} 44$ above, 122

59 ibid, with a reference to the Minister's book Fighting All the Way (London: Macmillan, 1993).

${ }^{60}$ For an overview of EU case law, compared with US case law, on positive/affirmative action, see van Gerven, n 18 above, 176-182.
} 
basis of which a candidate for a public post belonging to the underrepresented sex must be given preference over a candidates of the opposite sex when 'the difference between the merits of the candidates of each sex is not so great as to result in a breach of the requirement of objectivity in making appointments. ${ }^{91} \mathrm{But}$ that Article was not applicable to pay. With hindsight, one may wonder whether it would have been acceptable for the Court and/or its A.G. to use that Article by analogy in order to read into Article 119 EC some principle of substantive equality. That, I would think, would have gone too far. To apply the reasoning of A.G. Mazàk in Mangold (above), it is surely acceptable to derive from specific provisions a general principle, for example derive from Article 2 (4) Directive $76 / 207$ a principle of substantive equality - although, also that would imply a farreaching conclusion - but it would be unacceptable to derive another specific ground of substantive equality from the general principle. It may be permitted for scholars to make a suggestion in that sense to the legislature but it is not admissible for the Court or an A.G. to base a decision on such creative thinking. That brings me to the relationship between Scholarship and Advocate Generalship.

\section{THE ADVOCATE GENERAL AND LEGAL SCHOLARSHIP}

\section{BRIDGING JUDICIAL AND ACADEMIC WORK: SUBSTANTIVE EQUALITY REVISITED}

My reflection regarding this subject has been immensely facilitated thanks to the work done by two legal scholars, Noreen Burrows and Rosa Greaves, both professors at the University of Glasgow. 62 In an exhaustive book on The Advocate General and EC law, Burrows and Greaves examine not only general issues, such as the advocate general as a member of the ECJ and the contribution of the Opinions of A.G.s to fundamental concepts of Community law; they also select and comment the work of four advocate generals, each one in connection with a specific area of Community law. ${ }^{63} \mathrm{My}$ own selection - 'Walter van Gerven and the principle of equal treatment of men and women' - is certainly due to the fact of

61 ECJ, case C-407/98, Abrahamnsson, [2000] ECR I- 5539. In an earlier judgment, in case C-409/95, Marschall, [1997] ECR I-6363, the Court was quite outspoken with regard to the prejudices and sterrotypes which continue to work to the disadvantage of women. The Court stated: 'it appears that, even where male and female candidates are equally qualified, male candidates tend to be promoted in preference to female candidates particularly because of prejudices and stereotypes concerning the role and capacities in working life and the fear, for example, that women will interrupt careers more frequently, that owing to household and family duties they will be less flexible in their working hours, or that they will be absent from work more frequently because of pregnancy, childbirth and breastfeeding.' 62 n 44 above.

63 These are: Maurice Lagrange (the first Advocate General) and the creation of the Community legal order; myself and the principle of equal treatment of men and women; Francis Jacobs and intellectual property law; and Jean-Pierre Warner and competition law. 
having written a whole series of Opinions on gender equality, starting with the Opinion in Barber, ${ }^{64}$ but probably also to the fact that, before coming to the Court in 1988, I already had a long academic career in Community law - from the beginning of the sixties. That made me an obvious subject of research on the relation between advocate generalship and scholarship. Even more so, because of my deep conviction to which the authors refer, that it is the role of an A.G. to be a bridge between the Court and the legal community. ${ }^{65}$ In my own words: 'it is the AG's role to explain the case-law of the Court and make observations on it to help practitioners understand the reasoning of the Court and the system' and 'mak[e] the reasoning of the Court more transparent and therefore (more) democratic'.66 And, indeed, the authors describe my Opinions for better and for worse as being 'characterized by their scholarship. [They] are lengthy, extensively referenced and present comparative legal research, as well as being extremely analytical of both the factual and the legal analysis, and particularly detailed in respect of the variety of occupational pension arising in the cases'. ${ }^{67}$ These are surely the characteristics of scholarly work of the type described above (p. 13) as doctrinal and concrete scholarship, and judge-oriented, which is surely the category to which writings of AG's belong since they are, by definition and necessity, closely linked to judicial practice.

As mentioned above ( $\mathrm{p}$ 19), in their concluding observations Noreen Burrows and Rosa Greaves rightly observe that the straightforward and radical view which the Court and its AG took in Barber of Article 141 (ex 119) EC, was an expression of formal rather than substantive equality, in the sense that it sought not to recognize the difference between the burdens imposed by society on working women and working men. ${ }^{68}$ That is correct but, as mentioned before, this is precisely the difference between what an $A G$ is allowed to do and what a legal scholar may do: the AG (and the Court) must follow the law in the way they believe, after sound doctrinal reflection, that it must be interpreted; by contrast, a scholar may suggest to change the law and propose a form of reasoning which allows him or her to avoid the interpretation which is required in the current state of the law. Obviously, the legislature may change the law but in the case of Barber the Member States assembled as an IGC did not choose that direction but limited themselves to only clarify the Court ruling's temporal limitation clause. ${ }^{69}$

\footnotetext{
${ }^{64} \mathrm{n} 9$ above.

${ }^{65}$ A conviction which was strengthened by the fact that I knew that, after my six-years term as AG, I could not be renewed and would (have to) go back to academia.

${ }^{66} \mathrm{n} 44$ above, 92.

67 ibid, 91-92. To which the authors add the highest compliment a continental lawyer can earn (at least in my eyes): 'It is not surprising that his opinions read as if they were judgments in the House of Lords: they have almost common law quality about them ...' (italics added).

68 ibid, 122

${ }^{69}$ On this, ibid, $110-117$.
} 


\section{THE LIMITS AND MERITS OF ADVOCATE GENERALSHIP}

Burrows and Greaves' discussion of the limits of an A.G.'s 'judicial' Opinion - at the risk of his Opinion becoming a scholarly writing - is very much to the point. They observe that adding a substantial "intermediate question" as I did in Barber although it had to be done because the courts of the Member States were confused as to the correct interpretation of the Treaty - was not strictly necessary to assist the Court dealing with the question posed in the specific case. The Opinion could therefore be compared to doctrine as it is understood within civilian systems of law..$^{70}$ They even wondered whether I was not indulging my own academic interests but admitted that the Treaty does not limit the kind of assistance that can be given by the Advocate General to the case in question, and that the issues I raised in my Opinion in Barber were later referred to the Court in a number of subsequent cases. ${ }^{71}$ They add, rightly again, that I consciously wrote my Opinions in the style of a dissenting or concurring opinion in a common law court, although at the time of writing and delivering the Opinion I could not know the outcome of the case. They conclude in a friendly way, as all what preceeds: ' $\mathrm{He}$ addresses all of the issues ... in a systematic fashion, responding to the arguments in a systematic and structured way. ... He does not dismiss arguments out of hand but weighs each argument with a respect due to the lawyers before the Court. At the same time [he] remains the academic lawyer too.... [His] Opinions ... are extensively researched ... He shows himself aware of academic commentary on the Court and footnotes his Opinions with care .....$^{72}$

Let me add a few side remarks. A first remark is that, although the A.G.'s Opinion is signed by him alone and is drafted under his own responsibility, it constitutes nevertheless collective work in the sense that, depending on the nature and importance of the case, the legal secretaries ("référendaires") were - at least in my "cabinet" - always involved in the preliminary and sometimes final drafting of the Opinion. A second observation concerns the limits and off-limits of Advocate Generalship. Surely, Opinions of Advocate Generals should not be written for the sake of legal scholarship but to assist the Court - however, not necessarily only to assist the Court in the specific case. Indeed, when the AG writes an Opinion in one case, he is often aware of other cases touching on the same or similar issues which are pending before the Court and may well be assigned to him. In such circumstances he may use the Opinion in the first case to sketch a general framework in which later Opinions can be set. ${ }^{73} \mathrm{~A}$ final remark, already made before: surely the A.G.' s role is first to assist the Court, but not only; he is also at the service of the legal community, meaning that it is his task also to clarify the Court's case-law to that community, not the least the students' community, and to explain things to them which the judges know, or are supposed to know, but not

70 ibid, 104-105.

71 ibid, 105

72 ibid, 124

73 See ibid, $105 \mathrm{ff}$. 
necessarily the legal community at large. In that sense an A.G. is also a "public educator", especially in a community like the European Community which is a multi-legal, multi-language and multicultural community originating in very different legal systems and families with very different mentalities. It is the A.G.'s duty to take this factor into account and to contribute as much as possible, and reasonable, to making these differences comprehensible and comprehensive. Finally, as explained below, it is also the role of A.G.s to help Community law take roots in the laws of the Member States, i.e., to find general principles which the Member States have in common, and will therefore become principles of Community law.

All of the foregoing shows how different the role of an advocate general is compared with that of a judge in the Court: judges do not have the time and especially not the space to write down their opinion in a consistently written and orderly structured way, and do not have a role of bridge maker or public educator. ${ }^{74}$ Their task is to solve the problem before them in a fair and correct way.

\section{THE ADVOCATE GENERAL INITATOR OF COMPARATIVE LAW}

\section{THE EU OF 27 MEMBER STATES, A SHOWPLACE OF LEGAL DIVERSITY}

Diversity is not an evil in itself, no more or less than unity is a good in itself. Within the EU uniformity of Community laws or, in a lesser form, harmonization of national laws is only required when needed to achieve the objectives of the Union, that is mainly, in order to realize and maintain the establishment and functioning of the internal market (Articles 94 and $95 \mathrm{EC}$ ) and to avoid distortions of competition in interstate relations (Articles 81-83 EC). Beyond these objectives which necessitate binding Community legislation, regulations or directives in particular, diversity will continue to exist. That, however, should not prevent public and private actors, mainly educators, from promoting (non-binding) convergence of legal systems and mentalities, as it facilitates communication between EU citizens and residents in the many professions and occupations where frequent contacts increasingly occur. ${ }^{75}$ Convergence is especially needed in the legal field because of the large differences in mentalities between lawyers from the major and less major legal families (common law, Germanistic, Romanistic, Nordic, ...). Without convergence of mentalities, EU laws - even when laid down in binding

\footnotetext{
74 Which is why opinions of A.G. have footnotes, some more than others, to explain or refer where appropriate to Member States legal sources.

75 See further W. van Gerven, 'About Rules and Principles, Codification and Legislation, Harmonization and Convergence, and Education in the area of contract law' in A. Arnull, P. Eeckhout and T. Tridimas (eds.), Continuity and Change in EU Law. Essays in honour of Sir Francis Jacobs (Oxford: Oxford University Press, 2008) 400-414, at 409ff.
} 
rules - will be threatened to loose their homogeneity because of differences in understandings and interpretations. For indeed:

whoever wonders whether these differences in legal mentality still exist should compare judgments of the House of Lords with those of the French Cour de cassation and of the German Bundesgerichtshof. Only in a common law system is it possible for a judge to say in his decision that ' $[\mathrm{t}] \mathrm{he}$ state of a man's mind is as much a fact as the state of his digestion' or, more prosaically (and more recently), only in a common law system is it possible for a Law Lord (Lord Steyn) to express himself (in MacFarlane: $n 39$ above) on a delicate issue of 'wrongful life' in the following terms: 'I have not consulted my fellow travellers on the London Underground but I am firmly of the view that an overwhelming number ... would answer the question with an emphatic No'. By contrast, who would contradict the famous American judge Cardozo when he describes the decisional practice of German judges as 'march[ing] at times to pitiless conclusions under the prod of a remorseless logic which is supposed to leave no alternative'. And, as Cartesian as French judges may be, that does not show in the cryptic judgments of the Cour de Cassation which, following the style of legislative pronouncements, expresses its opinion with a minimum of justification or explanation. ${ }^{76}$

\section{GENERAL PRINCIPLES COMMON TO THE LAWS OF THE MEMBER STATES}

Whilst harmonisation through regulations or directives is part of the traditional Community method based on binding legislation, there are recently more and more areas where coordination of policies takes over from harmonization of laws. In those areas binding legislation is often replaced by convergence through soft law instruments and voluntary, even spontaneous, action on the part of public and private actors. ${ }^{77}$ One such area in which convergence occurs through principles, i.e., law that is more soft than hard, ${ }^{78}$ is referred to in Article 288 (2) (ex 215 (2)) EC relating to the non-contractual liability of Community institutions and their servants for damage caused by them to individuals in the performance of their duties. According to that Article, in combination with Article $235 \mathrm{EC}$, it is for the Court of Justice to decide disputes relating to such compensation 'in accordance with the general principles common to the laws of the Member States'. As is well known the jurisdiction of the ECJ relating to the granting of compensation in the case of non-contractual liability of Community institutions has been enlarged in the case law of the Court, starting with the Francovich judgment. ${ }^{79}$ In this judgment and later case law, the Court declares the principle of State liability to be a Community law principle that is inherent to the treaty. To reach that conclusion, it

\footnotetext{
76 For references and further developments, see n 40 above, 40-43.

77 van Gerven, n 75 above, 406-412.

78 On the difference between rules and principles (according to R. Dworkin), see ibid, 401-403.

79 ECJ, Cases C-6/90 and C-9/90, Francovich v Italy, [1991] ECR I-5357.
} 
relied on the duty of the national judges to ensure 'the full effectiveness of Community rules and the effective protection of the rights which they confer', and on 'the obligation to cooperate imposed on the Member States by Article 10 (then 5) of the (EC) Treaty'. ${ }^{80}$ Both liability systems, the one laid down in 288 (2) EC and the one set out in "Francovich" - the first directly applied by the ECJ, the second applied by the domestic courts under the guidance of the ECJ through preliminary rulings - respond in principle, i.e., unless particular justification for differentiation, to the same general principles. ${ }^{81}$

Obviously, with the growing number of Member States the task to find general principles common to the laws of the Member States has become increasingly difficult. It means in essence that comparative research is needed, ${ }^{82}$ for which the members of the ECJ, judges and A.G.s, do not have time or resources, and will need to rely mainly on their legal secretaries ("référendaires"), translators and civil servants in the documentation and research department of the Court. ${ }^{83}$ But also these Court civil servants have only time to study issues closely related to the cases on which the Court must render judgment. In this respect the contribution of the judges is different from that of the A.G.s. Whilst the former perform their task mainly within the framework of deliberations, ${ }^{84}$ each judge having his/her own legal system in mind, the latter are better placed to compare the different legal systems between themselves. An example thereof is the Opinion of A.G. Léger in Köbler concerning the liability of the State for infringements of Community law on behalf of a Member State's court deciding in last instance. ${ }^{85}$ In his Opinion the A.G., besides referring to international law, made his assumptions by relying on a comparative overview of the legal situation in the (then) fifteen Member States, all of which led him to the conclusion that:

all the Member States accept the principle of State liability for judicial acts. All - except for the moment Ireland - accept that principle in respect of

\footnotetext{
${ }^{80}$ Francovich, ibid, paras. 32-37; ECJ, Cases C-46/93 and C-48/93, Brasserie du Pêcheur and Factortame [1996] ECR I-1029, para. 39.

${ }^{81}$ Brasserie, ibid, para. 39, 42; ECJ, Case C-352/98P, Bergaderm and Goupilv Commission, ECR [2000] I-5291, para 41.

82 See W. Wurmnest, Grundzüge eines europäischen Haftungsrecht (Tübingen: Mohr Siebeck, 2003) 1618. On the comparative method of the Court, see K. Lenaerts, 'Interlocking legal orders or the European Union Variant of E Pluribus Unum' in G. Canivet et al. (eds), Comparative Law before the Courts (London: British Institute of International and Comparative Law, 2004), who writes at 105: 'the comparative law method, when applied by the Community judge, is driven by a single leitmotiv, and that is to find through the examination of other legal orders the solution which best suits the objectives of the Community.'

${ }^{83}$ Fashioning Community general principles drawn from the different Member States legal orders is of course not only the work of the Court, its members and very diverse staff of researchers, legal secretaries, translators and interpreters, but also the work of the legal staff working at the other Community institutions and of lawyers practicing Community law throughout the Union. As described elsewhere, as a whole it is a dialectical interaction between national laws and Community law. See my article on 'The emergence of a common law in the area of tort law: the EU contribution', in D. Fairgrieve, M. Andenas and J. Bell (eds.), Tort liability of public authorities in comparative perspective, (London: British Institute of International and Comparative Law, 2002) 125-147, at $138 \mathrm{ff}$.

${ }^{84}$ Called "personifierte Rechtsvergleichung": Wurmnest, n 82 above, 16.

85 Opinion in case C-224/01, Köbler v Austria [2003] ECR I-10239. See for a follow-up judgment: case C173/03, Traghetti v Italy [2006] ECR I-05177.
} 
judgments themselves where they infringe legal rules applicable in their territory, in particular where there is a breach of fundamental rights. ${ }^{86}$

In that respect, the Opinion of A.G. Leger and the Court's judgment in Köbler differ clearly from the Opinion of A.G. Tesauro and the Court's earlier judgment in Brasserie du Pêcheur in which the Court 'had, despite evidence to the contrary in the Member States' domestic structures, introduced the principle of State liability for legislative breaches of Community law. ${ }^{87}$ However, whatever the merit of A.G. Léger's Opinion, the comparative discussion remains limited: only eight out of 174 paragraphs of the Opinion were used to present the common principles shared by (then only) fifteen Member States. Unfortunately, that is not enough to be truly decisive. 88

\section{TOWARDS A EUROPEAN PUBLIC LEGAL SPACE AND OPINION}

The professional activities of Community judges and advocate generals will not suffice to reach the level of convergence that is needed to bring the Member State legal systems and mentalities enough close to one another, i.e., up to a point for a cross border European public legal space and opinion to be created. To reach that point an important contribution is needed from the academic world. Most important in my view is to make available learning and teaching material that can be used throughout the EU by academics, teachers and students, as well as practitioners, judges and advocates. When I left the Court in 1994, I therefore initiated, with funding from the University of Maastricht, a project called Ius commune casebooks for the common law of Europe which led to a first publication in 1998. ${ }^{89}$ In the foreword the objective of the book, meant to be a pilot project, and of the whole series was formulated as follows:

[This book ...] the authors hope will be used as teaching material in universities throughout Europe and elsewhere. The objective of this casebook and of the whole series is to help to uncover the common roots of the

86 Opinion, ibid, para 77 with further country-specific evidence in para. 80. For a more thorough presentation from which this paragraph is largely drawn, see K. M. Scherr, The Principle of State Liability for Judicial Breaches, thesis for the degree of Doctor of Laws of the European University Institute, 2008, 8-11.

87 Scherr, ibid, 9.

$88 \mathrm{ibid}, 10$. The author also points out that the A.G. did not reveal the method and the material he used in the course of his research.

${ }^{89}$ W. van Gerven, J. Lever QC and P. Larouche (C. von Bar and G. Viney cooperating), Cases, Materials and Text on TORT LAW, Scope of protection (Oxford: Hart Publishing, Oxford, 1998), v. Other books in the series, all of them being published by Hart Publishing, are comprehensive books on Tort Law (2000, same authors), on Contract Law (2002, Hugh Beale, Arthur Hartkamp, Hein Kötz \& Denis Tallon), Unjustified Enrichment (2003, J. Beatson, E. Schrage) and Non-discrimination law (2007, D. Schiek, L. Waddington, M. Bell). Other books to come are on Property law, and Consumer law. For further information see http:/www.law.kuleuven.ac.be/ccle. The method of the books has been described in my article, $\mathrm{n} 75$ above, 413-414. 
different legal systems, not to unify them. In other words, to strengthen the common legal heritage of Europe, not to strangle its diversity. ${ }^{90}$

That should be a common task for judiciary and scholarship.

90 At page $\mathrm{v}$ of the book, first cited in the preceding note. The books are frequently used in many European countries and the U.S., and the excerpted and commented on materials reproduced in the books, are often quoted by the academia and the judiciary, most prominently by the House of Lords. 